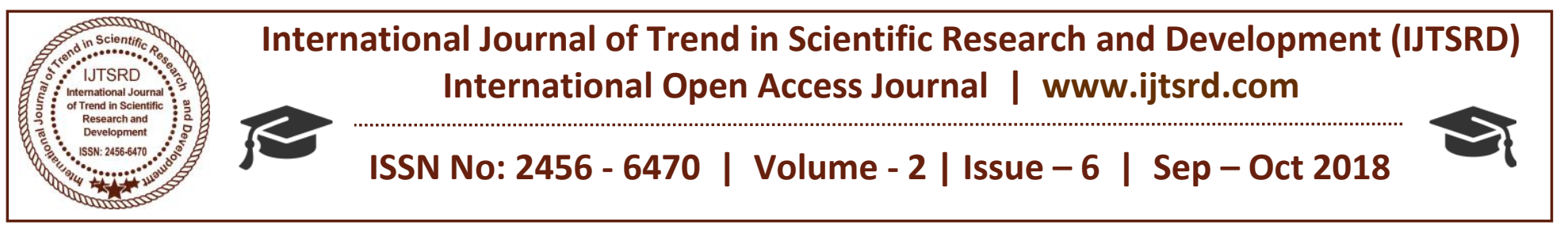

\title{
Milkweed Plantcalotropis, A Review
}

\author{
Sri Padmapriya. R ${ }^{1}$, Dr. Anita R. J. Singh ${ }^{2}$ \\ ${ }^{1}$ Research Scholar, ${ }^{2}$ Associate Professor
}

PG \& Research Department of Biotechnology, Women's Christian College, Chennai, Tamil Nadu, India

\begin{abstract}
A medicinal plant is one that can be used for traditional and therapeutic uses and is also a precursor for the synthesis of life saving drugs. Calotropisgigantea, Calotropis procera and Calotropis acia are some such plants. Calotropis gigantea, Calotropis procera and Calotropis acia belongs to the Asclepiadaceae family.The geographical distribution of Calotropis gigantea, Calotropis procera, and Calotropis aciahave been seen in several places throughout Asia.This review elaborates on the phytochemical composition and bioactive compounds and their therapeutic uses present in these plants. The vegetativeand floral characteristics of Calatropisgigantea, Calotropis procera and Calotropis acia have been differentiated for better understanding of these unique plants. The medicinal and pharmacological applications of Calotropis gigantea, Calotropis proceraand Calotropis aciahave been illustrated.
\end{abstract}

Keyword: Calotropis acia, Calotropis gigantea, Calotropis procera, International plant Index.

\section{INTRODUCTION}

The Indian systems of medicine has been a part of the culture and tradition of India down the centuries.[1]A medicinal plant is any plant which, in or most of it contains substance that can be used for therapeutic purpose or which is a precursor for the synthesis of useful drugs. The plant that posses therapeutic properties or exert beneficial pharmacological effects on the animal body are designated as "Medicinal plant" $[2,3]$. Calotropis is one among the most sorts after medicinal plant. Calotropis belongs to the Asclepiadaceae family. According to International Plant Name Index (IPNI), three species of Calotropis plants have been accepted for their therapeutic properties they are: Calotropis gigantea, Calotropis procera and Calotropis acia[4].

\section{Calotropis gigantea:-}

Calotropis gigantea is a shrub. It is drought resistant, salt-tolerant weed found roadsides, lagoon edges. It is used to treat rheumatism, indigestion, cold fever, ring worm of scalp, swelling, pain, tumour, piles. Different parts of the plant such as leaves, root, bark, flower and latex shows wound healing, anti -microbial, anticandida, anti-nematicide, anti-oxidant, and analgesic activity. [5]

\section{Calotropis procera:-}

Calotropis procera is also a shrub. It is drought resistant and salt-tolerant to a relatively high degree. All the parts of Calotropis procera are in common use in indigenous system of medicine. Different parts of the plant such as latex, leaves, root, bark and wood are used to treat ring worm, guinea worm blisters, scorpion stings, ophthalmic disorder, laxative, jaundice, toothache, sterility and whooping cough. They possess a number of biological activities such as proteolytic, antimicrobial, larvicidal, nematocidal, anti-cancer and anti-inflammatory. [6]

\section{Calotropis acia:-}

Calotropis acia is an under shrubs or herb. It is a strong medicinal plant. It is used to induce vomiting, purgation and used in the treatment of rheumatism, vitilgo, joint pains, mumps and ear-aches.

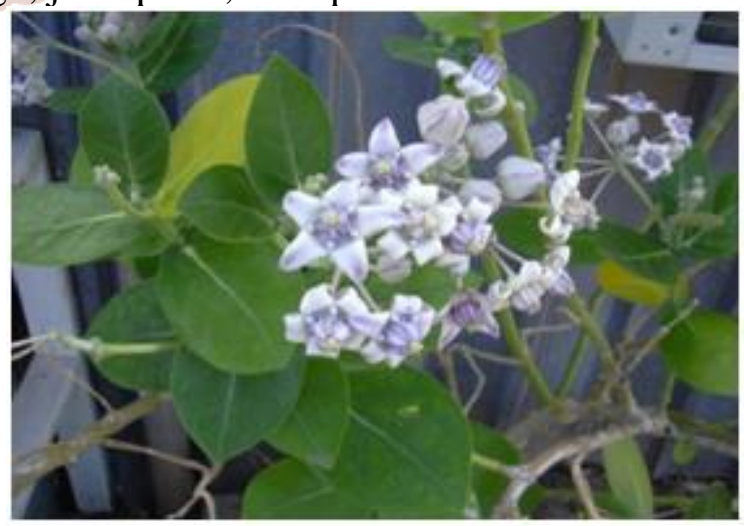

Fig.1: Calotropis gigantea 


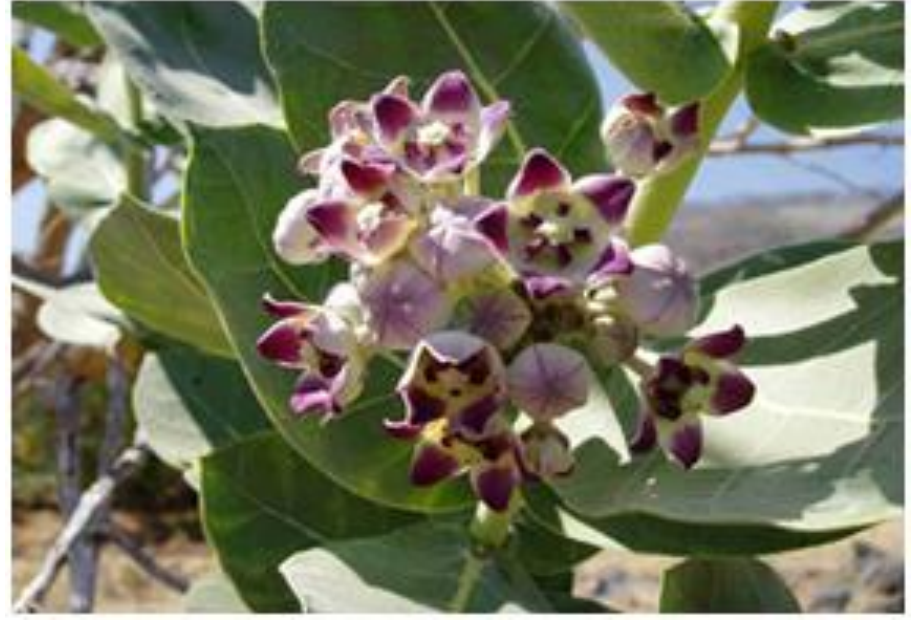

Fig.2: Calotropis procera

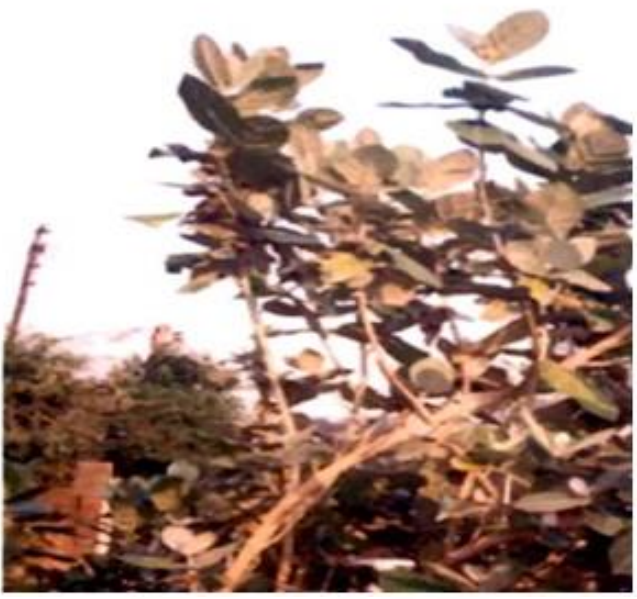

Fig.3: A plant of Calotropis acia

Systematic position of Calotropis gigantea,Calotropis procera and Calotropis acia[6,8]:-

\begin{tabular}{|l|l|l|l|}
\hline Classification & \multicolumn{1}{|c|}{ Calotropis gigantean } & \multicolumn{1}{|c|}{ Calotropis procera } & \multicolumn{1}{c|}{ Calotropis acia } \\
\hline Kingdom & Plantae-Plants & Plantae-Plants & Plantae-Plants \\
\hline Sub kingdom & $\begin{array}{l}\text { Tracheobionta-Vascular } \\
\text { plants }\end{array}$ & Tracheobionta-Vascular plants & $\begin{array}{l}\text { Tracheobionta-Vascular } \\
\text { plants }\end{array}$ \\
\hline $\begin{array}{l}\text { Super } \\
\text { division }\end{array}$ & $\begin{array}{l}\text { Spermatophyta-Seed } \\
\text { plants }\end{array}$ & Spermatophyta-Seed plants \\
\hline Division & $\begin{array}{l}\text { Mangliophyta-Flowering } \\
\text { plants }\end{array}$ & $\begin{array}{l}\text { Mangliophyta-Flowering plants } \\
\text { plants }\end{array}$ & $\begin{array}{l}\text { Mangliophyta- } \\
\text { Flowering plants }\end{array}$ \\
\hline Class & $\begin{array}{l}\text { Mangliopsida- } \\
\text { Dicotyledons }\end{array}$ & Mangliopsida-Dicotyledons & $\begin{array}{l}\text { Mangliopsida- } \\
\text { Dicotyledons }\end{array}$ \\
\hline Sub class & Asteridae & Asteridae & Asteridae \\
\hline Order & Gentianales & Gentianales & Gentianales \\
\hline Family & Apocynacea & Apocynacea & Apocynacea \\
\hline Sub Family & Asclepiadoideae & Asclepiadoideae & Asclepiadoideae \\
\hline Tribus & Asclepiadeae & Asclepiadeae 6 A7n & Asclepiadeae \\
\hline Sub Tribus & Asclepidinae & Asclepidinae & Asclepidinae \\
\hline Genus & CalotropisR.Br-Calotropis & Calotropis R.Br-Calotropis & Calotropis \\
\hline Species & Calotropis gigantea & $\begin{array}{l}\text { Calotropis procera(Aiton).W. T. Aiton- } \\
\text { rooster tree }\end{array}$ & acia \\
\hline
\end{tabular}

\section{Systematic position:-}

The Systematic position of Calotropis gigantea, Calotropis procera and Calotropis acia has been tabulated. [Table-1]

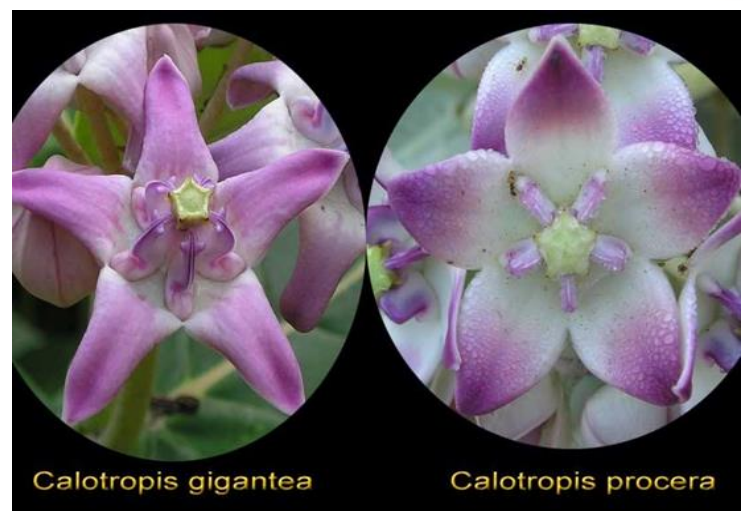

Fig.4: Flowers of Calotropis procera and Calotropis gigantea

Table-2:-Vernacular name $[6,2,10,11,12,13,15,16,17]$ 
International Journal of Trend in Scientific Research and Development (IJTSRD) ISSN: 2456-6470

\begin{tabular}{|c|c|c|c|}
\hline Languages & Calotropis gigantea & Calotropis procera & Calotropis acia \\
\hline English & $\begin{array}{l}\text { Crown flower, } \\
\text { Asclepiadaceae gigantea, } \\
\text { Giant Calotrope, Swallow- } \\
\text { wort, Giant Milk weed, } \\
\text { Kapal-kapal, bowstring hemp }\end{array}$ & $\begin{array}{l}\text { Mudra, Rooster tree, } \\
\text { Asclepiadaceae procera, Articula } \\
\text { tree, Dead Sea apple, Sodom } \\
\text { apple, Rubber brush ,French } \\
\text { cotton, Swallow-wort, Dead sea } \\
\text { fruit }\end{array}$ & $\begin{array}{l}\text { Madar, Giant Milk- } \\
\text { weed, Rooster tree } \\
\text {,Mudar plant }\end{array}$ \\
\hline Tamil & $\begin{array}{l}\text { Erukku, Malaiyerukku, } \\
\text { Arrkam, Yerkku }\end{array}$ & $\begin{array}{l}\text { Ekka, Yerkum, Vellai erukkan, } \\
\text { velai Erukku }\end{array}$ & Erukku \\
\hline Hindi & Aaka, Safed Aak, & Aaka, Aanka Ak & Madaar, Aak \\
\hline Sanskrit & $\begin{array}{l}\text { Alanka, Arki,Sadapushpa, } \\
\text { Hrasvagnih, Arka, Aditya }\end{array}$ & $\begin{array}{l}\text { Ark, Alanka, Ravi, } \\
\text { Adityapushpika, Alarka, } \\
\text { Ksirapara, Mandra }\end{array}$ & $\begin{array}{l}\text { Alarka, Rajaarka, } \\
\text { Shvetarka, Vauka, } \\
\text { Mandaar, } \\
\text { Bhasvanmuula, Dinesh, } \\
\text { Prabhakar }\end{array}$ \\
\hline Malayalam & $\begin{array}{l}\text { Erikkalachedi, Dinesam, } \\
\text { Vellerikk, Vellaerriku, } \\
\text { Chuvanneerikk }\end{array}$ & $\begin{array}{l}\text { Remiga, Rembega, Kemengu, } \\
\text { Erriku }\end{array}$ & Erukku \\
\hline Telugu & $\begin{array}{l}\text { Jilledi Puvvu, Uchcinta, } \\
\text { Nallajilledu, Uccinta }\end{array}$ & Erra jilledu, Jilledu, Mandaaramu & Uccinta \\
\hline Kannada & Ekka, Ekkemale, & Bili aekka, Bili aekkada gida & Ekka \\
\hline Marathi & Arki, Rui,Ruiti, Lal Arka & Mandara, Rui & Rui \\
\hline Gujarati & Akondo & Aankando & - \\
\hline Manipuri & Angkot intert & Numseubatong(Ao-Changki) & - \\
\hline Nepali & Aank, Madaar & $\begin{array}{l}\text { Setho Aank, Bahramasse Aank, } \\
\text { Aank }\end{array}$ & $=$ \\
\hline Assamese & Akonda, Akon & Akon reh and & -6 \\
\hline Turkish & Ipekag & Ipekag & - \\
\hline Spanish & Lechoso & $\begin{array}{l}\text { Algodon extranjero, Cazuela, } \\
\text { bomba }\end{array}$ & 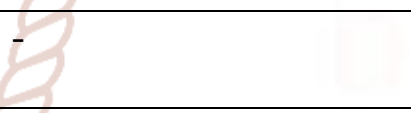 \\
\hline French & $\begin{array}{l}\text { Faux arbre de soie, Mercure } S \\
\text { vegetal }\end{array}$ & Calotrope, Pomme de Sodome & - \\
\hline Malaysia & Remiga, Rebinga,Kemengu & Rebinga, Kemengu & - \\
\hline Thai & Po thuean, Paan Thuean,Rak & Paan Thuen & - \\
\hline Vietnamese & $\begin{array}{l}\text { B[oot]ng b[oot]ng, 1[as]hen, } \\
\text { Namt[ot]b[at], Bang bien. }\end{array}$ & Saharo-sindish, cây lá hen & - \\
\hline Arabic & Ushar & $\begin{array}{l}\text { Ushar, Oshar, tourha, sano, } \\
\text { Fafetone, Dead sea Ushar }\end{array}$ & Oshar \\
\hline Japanese & Rubik & Rubik & - \\
\hline Laos & Kok may, Dok kap, Dok hak & Rèmbenga, kěmengu. & - \\
\hline Italian & Calotropo & Calotropo & - \\
\hline German & $\begin{array}{l}\text { Kronenblume, Madar- } \\
\text { Strauch, Mudarpflanze, } \\
\text { Akonfaserstrauch }\end{array}$ & Wahre Mudarpflanzer, Gomenier & - \\
\hline Chinese & Niu jiao gua & bai hua niu jiao gua & - \\
\hline Portuguese & Saco-de-velho & Algodao-de-seda;saco-de-velho & - \\
\hline Spanish & Mata de sela, Alogon de seda & $\begin{array}{l}\text { Alogon de seda,Algodon } \\
\text { extranjero, mata de sela }\end{array}$ & - \\
\hline
\end{tabular}

The Vernacular name of Calotropis gigantea, Calotropis procera and Calotropis acia has been tabulated. [Table-2] 
International Journal of Trend in Scientific Research and Development (IJTSRD) ISSN: 2456-6470

Table-3: Vegetative Character of Calotropis gigantea, Calotropis procera and Calotropis acia $[6,11,21,23,10]$

\begin{tabular}{|c|c|c|c|}
\hline $\begin{array}{l}\text { Vegetative } \\
\text { Characters }\end{array}$ & Calotropis gigantea & Calotropis procera & Calotropis acia \\
\hline $\begin{array}{l}\text { Habit and } \\
\text { Habitat }\end{array}$ & $\begin{array}{l}\text { It is a shrub or a small tree about } \\
4 \mathrm{~m} \text { tall. Crown flower grow in } \\
\text { any habitat, but it thrives in hot, } \\
\text { sunny anddryenvironment, } \\
\text { including the areas near the coast } \\
\text { that are exposed to salt. }\end{array}$ & $\begin{array}{l}\text { It is a shrub which is about } 3 \text { to } \\
6 \text { feet tall. The tender parts of } \\
\text { the plant and the under surface } \\
\text { of the leaves are covered with } \\
\text { white waxy secretion, called } \\
\text { latex. }\end{array}$ & $\begin{array}{l}\text { It is an herb or under } \\
\text { shrub. The tender parts of } \\
\text { the plant are covered } \\
\text { with floccose tomentose. }\end{array}$ \\
\hline Stem & $\begin{array}{l}\text { They are erect, branched and } \\
\text { herbaceous }\end{array}$ & $\begin{array}{l}\text { They are crooked and covered } \\
\text { with a fissured corky bark. } \\
\text { They are erect, branched, } \\
\text { glaborous, woody below and } \\
\text { herbaceous. }\end{array}$ & $\begin{array}{l}\text { They are erect, short, } \\
\text { branched and corky. }\end{array}$ \\
\hline Root & $\begin{array}{l}\text { They are simple, branched and } \\
\text { woody at the base and covered } \\
\text { with a fissured, corky bark. } \\
\text { Branches are succulent. They are } \\
\text { covered with tomentose (covered } \\
\text { with densely matted hairs) when } \\
\text { the plants are tender and in later } \\
\text { stage they become glaberescent } \\
\text { and glacous. }\end{array}$ & $\begin{array}{l}\text { They have a tap root consists } \\
\text { which is } 3-4 \mathrm{~m} \text { deep, and a } \\
\text { secondary root system with } \\
\text { woody lateral roots that may } \\
\text { rapidly regenerate adventitious } \\
\text { shoots when the plant is } \\
\text { injured. } \\
\text { ilonal Journal }\end{array}$ & - \\
\hline $\begin{array}{l}\text { Bark and } \\
\text { Branches }\end{array}$ & $\begin{array}{l}\text { The bark is racked and corky. } \\
\text { They grow wild on a variety of } \\
\text { soil in different climates. }\end{array}$ & $\begin{array}{l}\text { The bark is thick, rough and } \\
\text { corky and yellow-brown } \\
\text { colour; twigs are green and } \\
\text { fleshy and may have a } \\
\text { covering of tomentum (white } \\
\text { fur like hairs). Branches are } \\
\text { succulent and dense while } \\
\text { tomentose, glaberescent. }\end{array}$ & \\
\hline Leaves & $\begin{array}{l}\text { They are obovate or oblong, } \\
\text { sessile or with petiole. } 0.2-0.7 \mathrm{~mm} \\
\text { long; lamina elliptic to oblong. } \\
10 \mathrm{~cm} \text { long, } 3 \text { to } 8 \mathrm{~cm} \text { wide, } \\
\text { cordate to articulate, acute to } \\
\text { round. Colleters } 19 \text { or } 20 \text { pointed } \\
\text { at the tip and heart shaped at the } \\
\text { base. }\end{array}$ & $\begin{array}{l}\text { Simple,Cauline,sessile, opposit } \\
\text { e,decussate, exstipulate, } 2-5 \\
\text { inches,long, thick, glacous- } \\
\text { green, elliptical or obovate } \\
\text { oblong with cordate or often } \\
\text { amplexicaul base, acute or } \\
\text { shortly acuminate, unicosate } \\
\text { reticulate venation. }\end{array}$ & $\begin{array}{l}\text { They are oblong, } \\
\text { abruptly short, acute } \\
\text { lateral nerves about } 6- \\
7 \mathrm{~cm} \text { on both the sides. } \\
\text { The size of leaves varies } \\
\text { and ranges between } 12- \\
22 \mathrm{~cm} \text { in length and 5- } \\
13 \mathrm{~cm} \text { inches breadth. } \\
\text { Cuticle is thick and } \\
\text { entire. }\end{array}$ \\
\hline Flowers & $\begin{array}{l}\text { They have a faint odour, downy } \\
\text { on outside, arranged in axillary or } \\
\text { sub terminal. They have simple } \\
\text { or compound inflorescence. }\end{array}$ & $\begin{array}{l}\text { Flowers consist of five small } \\
\text { triangular dirty white sepals, } \\
\text { five thick ovate petals }(1 \times 1 \\
\mathrm{cm}) \text { which are white at the } \\
\text { base and purple at the tips and } \\
\text { they possess a white five lobed } \\
\text { stigma. }\end{array}$ & $\begin{array}{l}\text { Colour of the flower is } \\
\text { purplish. It is about } 1 \\
\text { inch in diameter. }\end{array}$ \\
\hline
\end{tabular}

The Vegetative character of Calotropis gigantea, Calotropis procera and Calotropis acia has been tabulated. (Table-3) 


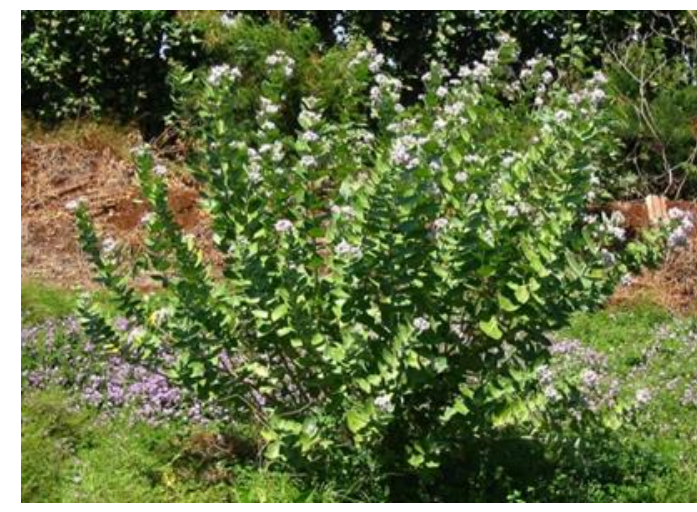

Fig.5: Calotropis gigantea shrub [23]

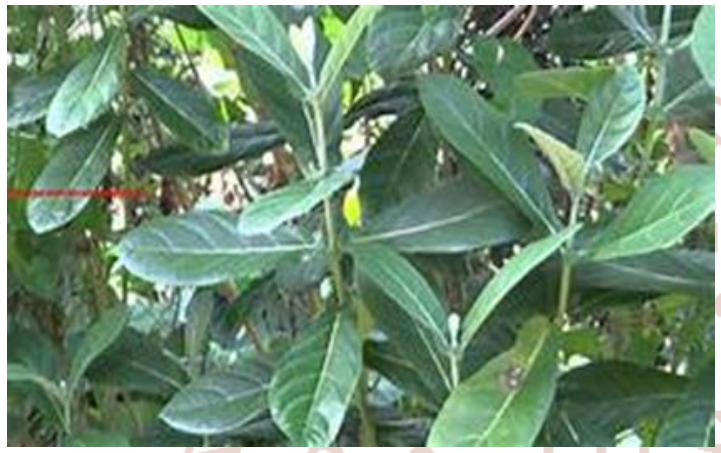

Fig.7: Calotropis gigantea leaves [25]

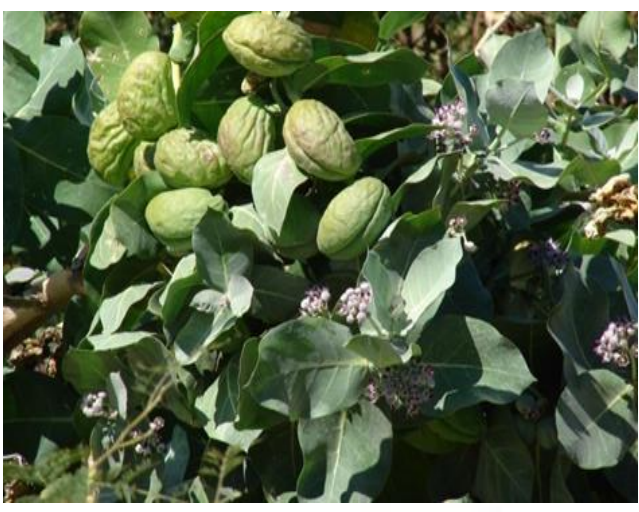

Fig.6 Calotropis procera shrub[26]

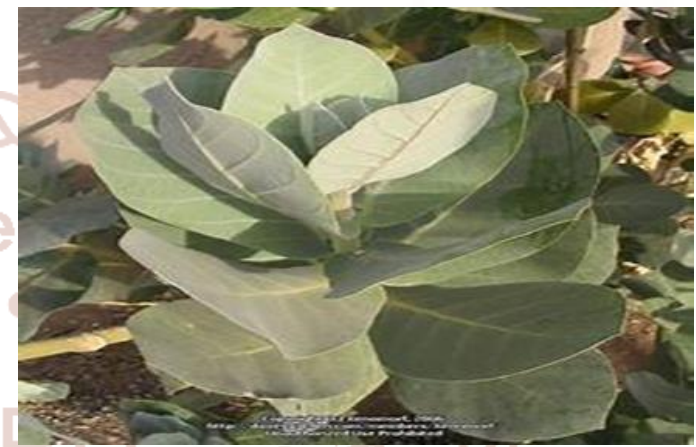

Fig.8 Calotropis proceraleaves[29]

Table-4:-Floral characters of Calotropis gigantea,Calotropis procera and Calotropis acia[30,14,34,25]

\begin{tabular}{|c|c|c|c|}
\hline $\begin{array}{c}\text { Floral } \\
\text { characters }\end{array}$ & Calotropis gigantea & Calotropis procera & Calotropis acia \\
\hline Flowers & $\begin{array}{l}\text { They are composed of } \\
\text { bracteate, complete, } \\
\text { actinomorphic } \\
\text { bisexual, hypogynous, } \\
\text { pedicellate and } \\
\text { pedicel upto } 1-3 \mathrm{~cm}\end{array}$ & $\begin{array}{l}\text { They are pentamerous } \\
\text { andhermaphroditic (both } \\
\text { androecium and gynoecium are } \\
\text { present in the same flower). } \\
6 S N=2456-6470\end{array}$ & $\begin{array}{l}\text { They are composed of } \\
\text { bracteate, pentamerous and } \\
\text { have pedicel. Flowering } \\
\text { occurs during cold weather } \\
\text { from December-March }\end{array}$ \\
\hline Inflorescence & $\begin{array}{l}\text { They appear in clusters } \\
\text { (umbellate cymes) }\end{array}$ & $\begin{array}{l}\text { They are composed of erect, } \\
\text { axillary, umbellate cymes and } \\
\text { polychasial cyme, one per axil. } \\
\text { Peduncle and pedicel are } \\
\text { present. }\end{array}$ & $\begin{array}{l}\text { Inflorescence are axillary and } \\
\text { terminal umbellate }\end{array}$ \\
\hline Calyx & $\begin{array}{l}\text { They consists of } \\
\text { fivesepals, } \\
\text { polypetalous,fivelobed, } \\
\text { shortly united at the } \\
\text { base, } \\
\text { glaberescent,quincidal } \\
\text { aestivation. }\end{array}$ & $\begin{array}{l}\text { They consistof } \\
\text { fivesepals,polysepalous, } \\
\text { quincidal. } \\
\text { They are five-lobed with many } \\
\text { glands at the base. }\end{array}$ & $\begin{array}{l}\text { Calyx are polysepalous, five } \\
\text { in number and lanceolate }\end{array}$ \\
\hline Corolla & $\begin{array}{l}\text { They have five petals } \\
\text { gamopetalous, five } \\
\text { lobed, twisted } \\
\text { aestivation }\end{array}$ & $\begin{array}{l}\text { They consistoffive petals, } \\
\text { gamopetalous, twisted and } \\
\text { coloured. }\end{array}$ & $\begin{array}{l}\text { Corolla lobes are erect, } \\
\text { acuminate with bluish purple } \\
\text { near the apex and whitish at } \\
\text { the base. }\end{array}$ \\
\hline Androecium & $\begin{array}{l}\text { They have five stamens, } \\
\text { gynadrous, and anther } \\
\text { dithecous and coherent. }\end{array}$ & $\begin{array}{l}\text { They have five Stamens, united } \\
\text { with the stigma to form } \\
\text { gynostegium (a specialized cap }\end{array}$ & $\begin{array}{l}\text { There are five numbers of } \\
\text { stamens which forms stamina } \\
\text { column with stigmatic disc to }\end{array}$ \\
\hline
\end{tabular}


International Journal of Trend in Scientific Research and Development (IJTSRD) ISSN: 2456-6470

\begin{tabular}{|c|c|c|c|}
\hline & & $\begin{array}{l}\text { like mass of tissue covering a } \\
\text { gynoecium); each stamen is } \\
\text { represented by two pollinia with } \\
\text { their retinaculae. The pollinia of } \\
\text { the adjacent anthers are joined } \\
\text { by their reticulanae to form } \\
\text { corpusculum in a groove to } \\
\text { form a unit known as translator. }\end{array}$ & form gynostegium. \\
\hline Gynoecium & $\begin{array}{l}\text { They have bicarpellary } \\
\text { apocarpousovary(having } \\
\text { carpels free from each } \\
\text { other) and styles are } \\
\text { united at their apex. } \\
\text { Pellate stigma with five } \\
\text { lateral stigmatic } \\
\text { surfaces. Anthers } \\
\text { adenate to the stigma } \\
\text { forming a gynostegium. }\end{array}$ & $\begin{array}{l}\text { They have two carpels, distinct, } \\
\text { ovaries free but upper portion of } \\
\text { style and stigma are fused, } \\
\text { superior, placentation marginal, } \\
\text { ovules many per locule, } \\
\text { pentagonal stigmatic head. }\end{array}$ & $\begin{array}{l}\text { They are bicarpellary, } \\
\text { apocarpous, ovary, superior } \\
\text { style, free stigma fused to } \\
\text { form stigmatic disc }\end{array}$ \\
\hline Fruit & $\begin{array}{l}\text { It is simple, fleshy, } \\
\text { inflated, and sub } \\
\text { globose to obliquely } \\
\text { ovoid follicles up to ten } \\
\text { cm or more in diameter. } \\
\text { Follicles are recurved up } \\
\text { to two or one follicles, } \\
\text { second more often } \\
\text { suppressed,3-4 inches } \\
\text { long. }\end{array}$ & $\begin{array}{l}\text { Fruit consists of an aggregate of } \\
\text { two dry follicles. They consist } \\
\text { of ovoids. Follicles were } 3-4 \\
\text { inches, recurved. } \\
\text { rnational Journal } \\
\text { rend in Scientific } \\
\text { Research and }\end{array}$ & $\begin{array}{l}\text { Pollination is antomophillus. } \\
\text { Fruiting occurs during cold } \\
\text { season from December to } \\
\text { March. }\end{array}$ \\
\hline Seed & $\begin{array}{l}\text { Seeds are broadly } \\
\text { ovate, up to } 5-7 \times 3- \\
4 \mathrm{~mm} \text {. }\end{array}$ & $\begin{array}{l}\text { They are flat obovate up to } \\
6 \times 5 \mathrm{~mm} \text { with silky white pappus } \\
\text { which is up to } 3 \mathrm{~cm} \text { or longer. }\end{array}$ & \\
\hline
\end{tabular}

The floral characters of Calotropis gigantea,Calotropis procera and Calotropis acia have been tabulated.

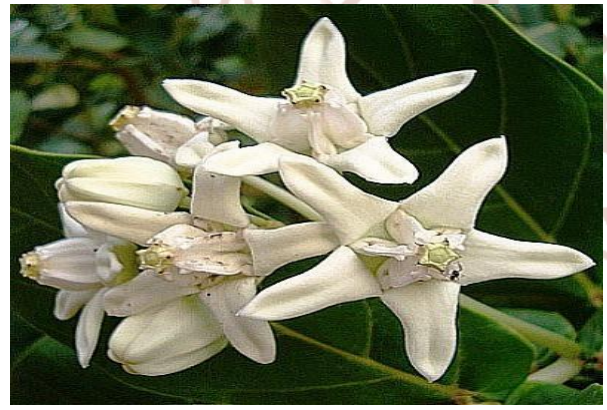

Fig.9: Calotropis gigantea flower [27]

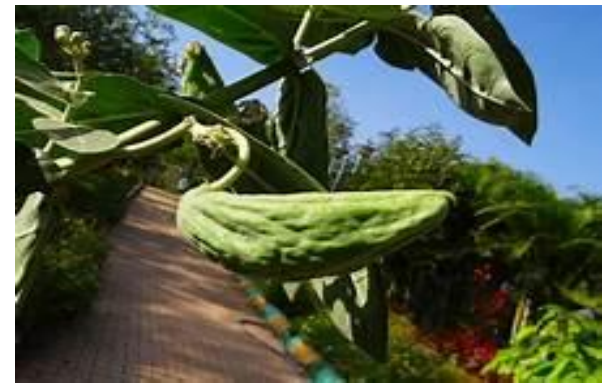

Fig.11: Milk weed-Calotropis gigantea fruit [30]

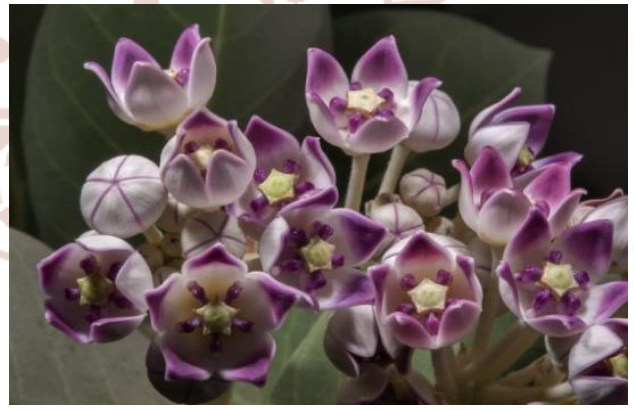

Fig.10: Calotropis procera flower [26]

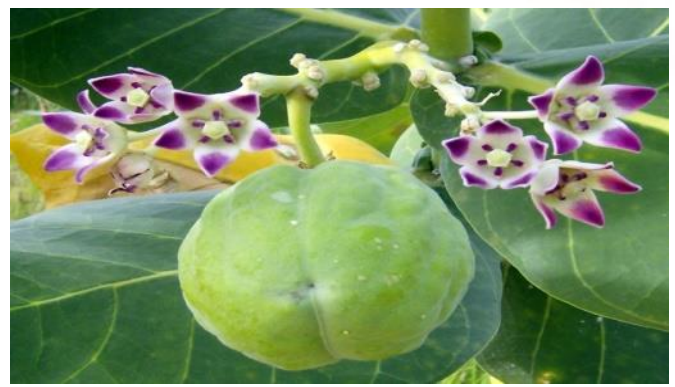

Fig.12: Calotropis procera fruit [29] 


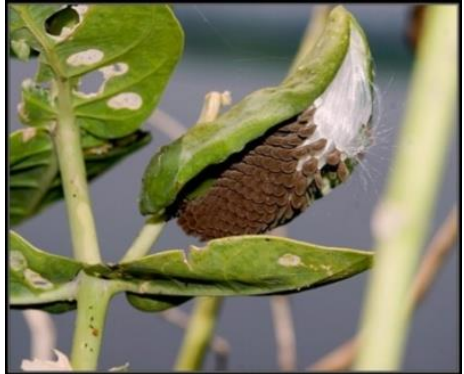

Fig.13: Calotropis gigantea seeds [33]

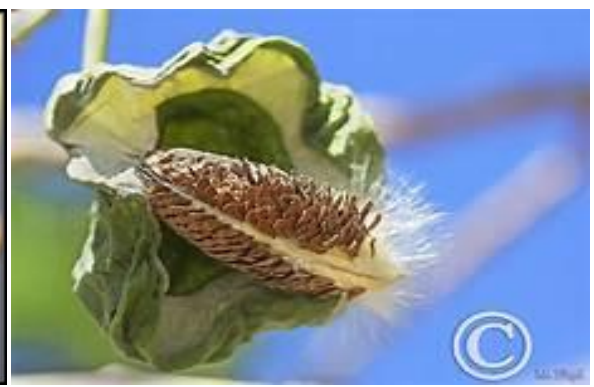

Fig.14: Calotropis

proceraseeds [32]

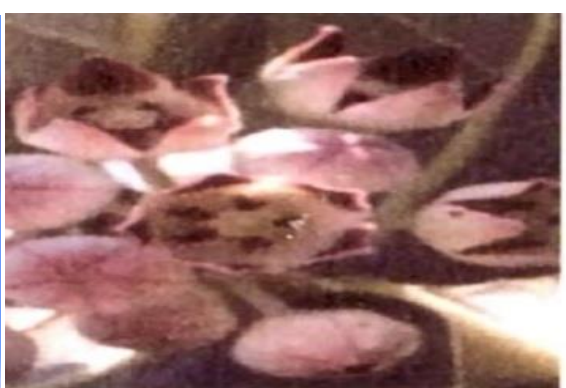

Fig.15: Calotropis

acia-Inflorescence [14]

\section{Geographic distribution:}

\section{Calotropis gigantea:-}

Calotropis giganteais common plants which are found in a warm climate in dry, sandy and alkaline soil. In India, it is found throughout the plains and lower hills, usually near water growing up to an altitude of $900 \mathrm{~m}$ including Andaman.[5]. It is grown in Africa, South east Africa, Eastern Asia.[36]. It is native in India to Sri Lanka, Iran to China, Malaysia, Indonesia, Africa-Asia.[5]

\section{Calotropis procera:-}

Calotropis procera is dominant in areas of abandoned cultivation especially sandy soils in the areas of low rainfall: assumed to be an indicator of over-cultivation. This plant is widely distributed in tropical and subtropical Africa and Asia.[37].It is native to India, Pakistan, Iran, Pakistan, Nepal, Afghanistan, Algeria, Israel, Kenya, Kuwait, Niger, Nigeria, Oman, Saudi Arabia, United Arad Emirates, Yemen, and Zimbabwe. [6].

\section{Calotropis acia:-}

Calotropis acia are found in India, Nepal, East, ${ }^{-}$North East India, Tropical Himalayas, Assam, Kamrup, Goalpara and Darjeeling. [38]

Table-5:Phyto chemical studies of Calotropis species

\begin{tabular}{|c|c|c|c|c|c|c|c|c|c|c|c|c|c|}
\hline \multirow{3}{*}{$\begin{array}{l}\text { S. } \\
\mathbf{N} \\
\mathbf{0}\end{array}$} & \multirow{3}{*}{$\begin{array}{c}\text { Experime } \\
\mathrm{nt}\end{array}$} & \multicolumn{6}{|c|}{ Calotropis gigantea $[40,43,5,41]$} & \multicolumn{6}{|c|}{ Calotropis procera $[39,6,73]$} \\
\hline & & \multirow{2}{*}{$\begin{array}{c}\begin{array}{c}\text { A queous } \\
\text { extract }\end{array} \\
\text { Root }\end{array}$} & \multicolumn{2}{|c|}{$\begin{array}{c}\text { Methanolic } \\
\text { Extract }\end{array}$} & \multicolumn{2}{|c|}{$\begin{array}{l}\text { Ethanolic } \\
\text { Extract }\end{array}$} & \multirow{2}{*}{$\begin{array}{c}\text { Benzene } \\
\text { Extract } \\
\text { Root }\end{array}$} & \multicolumn{3}{|c|}{$\begin{array}{l}\text { Petroleum ether } \\
\text { Extract }\end{array}$} & \multicolumn{3}{|c|}{$\begin{array}{c}\text { Methanolic } \\
\text { Extract }\end{array}$} \\
\hline & & & Root & $\begin{array}{l}\text { Lea } \\
\text { ves } \\
\end{array}$ & Stem & Root & & $\begin{array}{c}\text { Flo } \\
\text { wers } \\
\end{array}$ & $\begin{array}{l}\text { Lea } \\
\text { ves } \\
\end{array}$ & $\begin{array}{c}\text { Ste } \\
\mathbf{m} \\
\end{array}$ & $\begin{array}{l}\text { Flo } \\
\text { wers } \\
\end{array}$ & $\begin{array}{l}\text { Lea } \\
\text { ves } \\
\end{array}$ & $\begin{array}{l}\mathrm{St} \\
\mathrm{em} \\
\end{array}$ \\
\hline 1 & Alkaloids & + & + & + & + & + & +0 & + & - & - & - & - & - \\
\hline 2 & $\begin{array}{c}\text { Carbohydr } \\
\text { ates }\end{array}$ & + & - & - & + & + & & 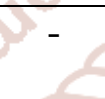 & - & - & + & + & - \\
\hline 3 & Flavonoids & + & - & + & - & + & + & - & - & - & + & + & + \\
\hline 4 & Glycosides & + & - & + & - & - & + & + & + & - & + & + & + \\
\hline 5 & $\begin{array}{l}\text { Tannins \& } \\
\text { Phenolic } \\
\text { compound }\end{array}$ & + & - & + & - & + & - & - & - & + & + & + & + \\
\hline 6 & Saponins & + & - & + & - & + & + & + & - & + & + & - & + \\
\hline 7 & $\begin{array}{c}\text { Proteins } \\
\text { and amino } \\
\text { acids }\end{array}$ & + & + & - & + & - & - & + & + & + & + & + & + \\
\hline 8 & $\begin{array}{c}\text { Fats and } \\
\text { oils }\end{array}$ & - & + & + & + & - & + & + & - & + & + & - & + \\
\hline 9 & $\begin{array}{c}\text { Triterpenoi } \\
\text { ds }\end{array}$ & - & + & + & + & - & - & - & + & - & + & + & - \\
\hline 10 & $\begin{array}{c}\text { Reducing } \\
\text { sugar }\end{array}$ & + & - & - & + & + & - & - & - & - & + & - & - \\
\hline 11 & Steroids & - & + & + & - & - & + & - & + & - & + & + & - \\
\hline
\end{tabular}

The phytochemical studies of Calotropis gigantea, Calotropis procera \& Calotropis acia have been tabulated. 
\#-Calotropis acia: Relevant information not available. Medicinal applications and Pharmacological activities of Calotropis gigantea and Calotropis procera:-

\section{Anti-bacterial activity:-}

In-vitro anti-bacterial activity of methanol extract of Calotropis gigantea leaves against Salmonella typhi, Pseudomonas fluorescens, Pseudomonas aeruginosa and Escherichia coli was done. This study showed clear indication that Calotropis gigantea had positive effect on Pseudomonas fluorescens. [2]

Studies on the growth and survival dynamics of Escherichia coli, Staphylococcus aureus, Candida albicans and Xanthomonas campestr is of Ethanolic extracts of apical buds and flowers have shown higher growth in Calotropis gigantea which had a good effect on E. coli, S. aureus and C. albicans.[43]

The antagonistic activity of aqueous extract against Staphylococcus aureus, Escherichia coli, Bacillus cerus, and Pseudomonas aeruginosa, Micrococcus luteus and Klebsiella pneumonia revealed that Calotropis gigantea had the maximum zone of inhibition against Escherichia coli whereas lowest inhibition was seen against Klebsiella pneumonia. [44].

\section{Hepatoprotective activity of Liver:}

The suspension of alcoholic extract of root and bark of Calotropis gigantea, dissolved in $0.6 \%$ (carboxy methyl cellulose) CMC was evaluated for hepatoprotective activity in Wistar rats by inducing hepatic injury with D-galactosamine. [42].

\section{Larvicidal and Repellent activites:-}

The larvicidal efficiency of the latex of Calotropis procera against all three important vector species such as Ae, aegypti, An stephesi and Cx. quinqefaciatus, vectors of dengue, malaria and Lymphatic filarius respectively in which it was proved that Calotropis procera latex is responsible for the larvicidal properties [45].

The anti-feedant activity of Calotropis procera leaves was seen against third instar larvae of Spodoptera lithura done by dip method in extract. The maximum activity detected in chloroform extract. [50]

\section{Synthesize of Nanoparticles:-}

Thesynthesis of silver nanoparticles (AgNPs) by using serum latex of Calotropis procera at $80^{\circ} \mathrm{Cinferred} \mathrm{that}$ the AgNPs showed strong antibacterial activity against Escherichia coli, Pseudomonas aeruginosa and Serratia sps and Anti-fungal activity against Trichophyton rubrum, Candida albicans and Aspergillus terreus. [46]

The green synthesis of Zinc oxide $(\mathrm{ZnO})$ particles by Zinc nitrate, utilizing the bio components of the leaf extract of Calotropis gigantea has been analysed by X-Ray Diffraction (XRD) and Scanning electron microscopy (SEM) and calculated using DebyeScherrer's method and represented graphically. [47]

\section{Cytotoxicity:-}

The sub-acute toxicity study conducted for 28 days with ethanolic and methanolic extract of Calotropis gigantean latex in mouse models suggested that Calotropis gigantea latex does not cause sub-acute toxicity till the level of $1000 \mathrm{mg} / \mathrm{kg}$ body wt./day for 28days and hence is considered as a phyto medicinal therapeutic agent.

\section{Abortificient activity:-}

Calotropin isolated from the roots of Calotropis procera when administered to gerbils and rabbits $(25 \mathrm{mg} / \mathrm{kg} \mathrm{b}$. wt) each day for a period of 30 daysinhibited the process of spermatogenesis in male and induced abortion in pregnant females. [49]

\section{Nephrotoxic Activity:-}

The ethanolic extract of leaves of Calotropis proceraon kidney function and histological integrity in male albino rats indicated that Calotropis procera latex and ethanolic extract of leaves could induce marked toxicity in kidney and the semay be more or less prone to those of abamectin. [48]

\section{Anti-diarrhoeal activity:-}

The anti-diarrhoeal effects of hydro alcoholic extract of aerial parts of Calotropis giganteaagainst castor oil induced diarrhoea model in rats indicated that it possesses anti-diarrhoeal effect against castor oilinduced diarrhoea in a wide range of diarrhoeal states. [51]

It was observed that the anti-diarrhoeal activity of ethanolic extract of root of Calotropis procera against castor oil induced diarrhoea in rat showed that the extract controlled the condition. [53]

\section{Anthelmintic activity:-}

The anthelmintic efficiency of ethanolic and aqueous extracts of flower of Calotropis procera against 
trematode parasite, Gastrothylax indicus showed that the motility and survival of the parasite and inhibition caused in the tegmental enzymes is due to the effect of Calotropis procera flowers which acted as a potential vermifuge or vermicide. [52]

\section{Antioxidant activity:-}

Methanolic extract of Calotropisprocera stem and leaves on potato dextrose agar medium (PDE) was used to extract and isolate eight endophytic fungi among them two fungi were found to be Penicillium spp and Aspergillus spp. The isolated fungal species showed the presence of flavonoids and phenolic coumpounds. [54]

\section{Extraction of oil:-}

The essential oil from the dried leaves of Calotropis procera was analysed by GC-MS. The two major components- 3, 7, 11, 15-tetramethyl-2-hexadecene-1ol and 6, 10, 14-trimethyl-2-pentadecanone are used to control arthritis and malaria.[55]

\section{Control of Struvite crystals}

Struvite crystals comprised of calcium phosphate, calcium oxalate and magnesium phosphate. The results showed the increase in concentration of methanol extract of Calotropis gigantea leaves reduced the growth and nucleation rate of Struvite crystals. The compound identified and isolated/characterised by HPTLC and NMR techniques. [67]

Table.6:-Bio active compounds extracted from Calotropis species

\begin{tabular}{|c|c|c|c|c|}
\hline $\begin{array}{l}\text { S. } \\
\text { no }\end{array}$ & Compounds & $\begin{array}{l}\text { Common name or IUPAC name of } \\
\text { the compound }\end{array}$ & $\begin{array}{c}\text { Calotropis } \\
\text { gigantea }\end{array}$ & \begin{tabular}{|c|c|} 
Calotropis \\
procera
\end{tabular} \\
\hline 1) & Phytol[55],[56] & 3,7,11,151-tetramethyl-2-hexadecen1-ol & Present & Present \\
\hline 2) & $\begin{array}{l}\text { 6,10,14-trimethyl-2- } \\
\text { pentadecanone[55] }\end{array}$ & Farnesyl acetone & $\#$ & Present \\
\hline 4) & $\begin{array}{l}3,7,11,15 \text {-tetramethy- } \\
\text { 2hexadecene-1-ol[55],[56] }\end{array}$ & Phytolional Jour & Present & Present \\
\hline 5) & $\begin{array}{l}\text { 3-Buten-2-one-4,2,6,6-trimethyl-1- } \\
\text { cyclohexne-1 yl[55] }\end{array}$ & Cyclocitryideneacetone IIC & $\#$ & Present \\
\hline 6) & 1-Nonadecene[55] & Nondec-1-ene & \# & Present \\
\hline 7) & $\begin{array}{l}\text { 5,9,13-pentadecatriene-2-one- } \\
\text { 6,10,14-trimethyl[55] }\end{array}$ & Farnesyl acetone ent & \# & Present \\
\hline 8) & Z-5-Nonadecene[55] & (Z)-nonadec-5-ene $=70$ & $\#$ & Present \\
\hline 9) & Hexadecanal[55] & Palmitaldehyde & \# & Present \\
\hline 10) & 9-Nonadecene[55] & (E)-9-Nondecene & \# & Present \\
\hline 11) & Octadecadienal[55] & Linoleyl aldehyde & \# & Present \\
\hline 12) & 1-Hexadecanol-2-methyl [55] & 2-Methylhexadecan-1-ol & \# & Present \\
\hline 13) & $\begin{array}{l}\text { 4,8,12,16-Tetramethylheptadecan- } \\
\text { 4-olide[55] }\end{array}$ & 2(3H)-Furan one & $\#$ & Present \\
\hline 14) & $\begin{array}{l}\text { 2-Butanone-4,2,6,6-trimethyl-1- } \\
\text { cyclohexen-1-yl [55] }\end{array}$ & Dihydro-beta-ionone & \# & Present \\
\hline 15) & 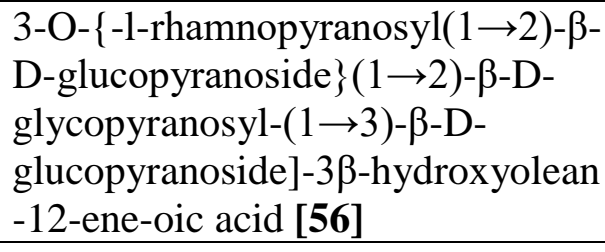 & Oleanolic acid & \# & Present \\
\hline 16) & $\begin{array}{l}\text { 33-Hydroxy olean-12-ene-28-oic } \\
\text { acid-28-O- } \beta \text {-D glucopyranoside } \\
\text { [56] }\end{array}$ & Oleanolic acid & \# & Present \\
\hline 17) & Furan-2-carbaldehyde [57] & Furfural & Present & \# \\
\hline 18) & 3-Hexyn-1-ol[57] & Cis-3-Hexen-1-ol;Blatteralkohol & Present & \# \\
\hline 19) & Gentanol[57] & Heptan-1-ol & Present & \# \\
\hline 20) & Benz aldehyde[ 57] & Melonol & Present & \# \\
\hline
\end{tabular}


International Journal of Trend in Scientific Research and Development (IJTSRD) ISSN: 2456-6470

\begin{tabular}{|c|c|c|c|c|}
\hline 21) & 2-Methyl-6-hepten-1-ol [57] & 6-Hepten-1-ol,2 methyl & Present & \# \\
\hline 22) & 6-Methyl-5-hepten-2-ol [57] & Sulatacol & Present & \# \\
\hline 23) & $(+) \beta$-citronellene [57] & D-Rhodinol & Present & \# \\
\hline 24) & 4-methyl-1-heptenol [57] & Isobutylene & Present & \# \\
\hline 25) & Cis-Linalool oxide [57] & Linalool oxide-B & Present & \# \\
\hline 26) & $\begin{array}{l}\text { 2,2,6-Trimethyl-1,4- } \\
\text { cyclohexandione [57] }\end{array}$ & Tetrahydro-2,2,6trimethyloxane & Present & \# \\
\hline 27) & Phenethyl alcohol [57] & Benzyl alcohol & Present & \# \\
\hline 28) & Oct-3-en-2-ol [57] & CIS-3-Oct-1-ol & Present & \# \\
\hline 29) & 3-Thiophenemethanol [57] & Thiophen-3-ylmethanol & Present & \# \\
\hline 30$)$ & n-Eicosane[57],[59],[61] & Icosane & Present & Present \\
\hline 31) & $\begin{array}{l}\text { Tetradecanoic acid, trim ethyl } \\
\text { ester[57] }\end{array}$ & Methyl myrisate & Present & \# \\
\hline 32) & Diisobutyl phthalate[57] & $\begin{array}{l}\text { 1,2-benzene dicarboxylic acid, bis(2- } \\
\text { methyl propyl ) ester }\end{array}$ & Present & \# \\
\hline 33) & Stearic acid[57] & Cetylacetic acid & Present & \# \\
\hline 34) & n-Tetracosane[57] & Lignocerane & Present & \# \\
\hline 35$)$ & n-Docasane[57] & Heneicosane & Present & \# \\
\hline 36) & DL-Menthol[57] & Bis(hydroxymethoxy)ethane & Present & \# \\
\hline 37$)$ & Nerol [57] & Cis-Geraniol & Present & \# \\
\hline 38) & $\alpha$-Terpiene [57] & $\begin{array}{l}\text { 1-Isopropyl-4-methyl-1,3- } \\
\text { cyclohexadiene,p-Menth-1,3, diene }\end{array}$ & Present & \# \\
\hline 39) & Undecane[57] & Hendecane & Present & $\#$ \\
\hline 40) & 2,3,epoxygeranyl acetate[57] & $\begin{array}{l}\text { 6,7-Epoxy-3,7-dimethyl-2-octene-1-ol } \\
\text { acetate in Scientific }\end{array}$ & Present & \# \\
\hline 41) & 2,4-dimethyl-Acetophenone[57] & Ethanone & Present & $\#$ \\
\hline 42) & Isocyclogeraniol [57] & $\begin{array}{l}\text { 2,4,6 Trimethyl-3-cyclohexene-1- } \\
\text { methanol }\end{array}$ & Present & \# \\
\hline 43) & n-Tridecane[57] & n-undecyclic acid & Present & \# \\
\hline 44) & \begin{tabular}{|l|} 
Gardenol [57] \\
\end{tabular} & Styrallyl acetate & Present & \# \\
\hline 45) & Dill ether [57] & Anethofuran $0=04 / 0$ & Present & \# \\
\hline 46) & Heptylidene acetone[57] & 3-Decen-one & Present & \# \\
\hline 47) & 4-vinylguaicol[57] & 2-Methoxy-4-vinyl phenol & Present & \# \\
\hline 48) & p-Cymen-7-ol [57] & 4-(1-methylethyl)benzene methanol & Present & \# \\
\hline 49) & p-Cyclocitral [57] & $\begin{array}{l}\text { Trimethylcyclohexene -1- } \\
\text { carbaldehyde }\end{array}$ & Present & \# \\
\hline 50) & Pinocamphenol [57] & Isopinocamphone & Present & \# \\
\hline 51) & Eugenol [57] & 4-Allyl-2-methoxyphenol & Present & \# \\
\hline 52) & Pinocamphenol [57] & 3-pinanone & Present & $\#$ \\
\hline 53) & Artemisia alcohol [57] & 1,5-Heptadien4-ol,3,3,6 trimethyl & Present & $\#$ \\
\hline 54) & $\begin{array}{l}\text { 3-Phenyl-2-propenoicacid, methyl } \\
\text { ester[57] }\end{array}$ & Cinnamic acid & Present & \# \\
\hline 55) & (Z)-Amylcinnamaldehyde[57] & 2-Benzylideneheptanal & Present & \# \\
\hline 56) & Spathulenol [57] & 1H-Cycloprop(E)azulen-7-ol & Present & \# \\
\hline 57) & Ribitol,TMS [57] & $\begin{array}{l}\text { Ribitol,1,2,3,4,5-pentakis-o- } \\
\text { (trimethylsilyl)ether }\end{array}$ & Present & \# \\
\hline 58) & Nerylacetone[57] & Cis-Geranylacetone & Present & $\#$ \\
\hline 59) & (E) $-\beta$-Ionone[57] & Sesquiterpenes & Present & \# \\
\hline 60) & $\begin{array}{l}\text { 5-hydroxy-3,7- } \\
\text { dimethyoxyflavone-4'-O- } \beta \text { - } \\
\text { glucopyranoside [58] }\end{array}$ & $\begin{array}{l}\text { 7,4'Di-O-Methylapigenin-5-O- } \\
\text { glucoside }\end{array}$ & $\#$ & Present \\
\hline
\end{tabular}


International Journal of Trend in Scientific Research and Development (IJTSRD) ISSN: 2456-6470

\begin{tabular}{|c|c|c|c|c|}
\hline 61) & 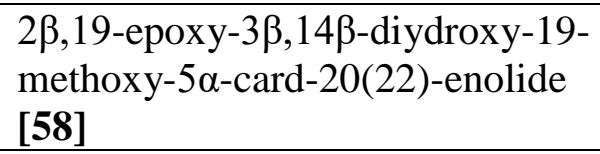 & Digitoxins & \# & Present \\
\hline 62) & $\begin{array}{l}\beta \text {-andydroepidigitoxigenin-3 } \beta \text {-O- } \\
\text { glucopyranoside [58] }\end{array}$ & $\begin{array}{l}\text { 3,4,5Trihydroxy-6- } \\
\text { (hydroxymethyl)oxan-2yl]benzoate }\end{array}$ & \# & Present \\
\hline 63) & Uzarigenine[58] & Odorigenin-B & \# & Present \\
\hline 64) & $\beta$-anhydroepidigitoxigenin [58] & Unidigin & \# & Present \\
\hline 65) & 1-Octanol-3,7-dimerhyl [59] & Dihydrocitonella & Present & \# \\
\hline 66) & $\begin{array}{l}\text { 2-Methoxy 4-vinyl phenol } \\
\text { ethanone [59] }\end{array}$ & 4-ethenyl-2-methoxyphenol & Present & \# \\
\hline 67) & Azulene [59] & Cycloheptane & Present & \# \\
\hline 68) & Benalaxyl [59] & Galben & Present & $\#$ \\
\hline 69) & $\begin{array}{l}\text { Beryllium sulphate tetra } \\
\text { hydrate[59] }\end{array}$ & Beryllium monosulphate tetra hydrate & Present & \# \\
\hline 70) & Biphenyl [59] & Limonene & Present & \# \\
\hline 71) & Campesterol [59] & Campest-5-en-3-beta-ol & Present & \# \\
\hline 72) & $\begin{array}{l}\text { Cholest-5-en-3- } \\
\text { ol,24,Propylidene }(3 \beta)[59]\end{array}$ & 24-Propylidenecholest-5-en-3 $\beta$ & Present & \# \\
\hline 73) & Levomenol [59] & Bisobolol & Present & \# \\
\hline 74) & Profenofos[59] & Curacron & Present & \# \\
\hline 75) & Butane-2,2-dimethyl [59] & Neohexane & Present & \# \\
\hline 76) & Cis-vaccenic acid [59] & Asclepic acid & Present & \# \\
\hline 77) & B-Tocopherol [59] & Cumotocopherol & Present & \# \\
\hline 78) & Z-1,6-Tridecadiene[59] & 1,11-Tridecadiene-3,5,7,9-tetrayne & Present & $\#$ \\
\hline 79) & L-Glutamic acid[59] & (S)-2-Aminopentanedioic acid & Present & \# \\
\hline 80$)$ & Phenol,2,5-bis(1,1-dimethyl)[59] & 2,6,-Di-tert-butylphenol & Present & \# \\
\hline 81$)$ & 5-Nondecen-1-ol [59] & - esearcinano & Present & $\#$ \\
\hline 82) & $\begin{array}{l}\text { D-Mannose-1-phosphate sodium } \\
\text { salt [59] }\end{array}$ & a-D-Mannopyranosyl phosphate & Present & \# \\
\hline 83) & Guanidine nitrate[59] & Guanidine mononitrate & Present & $\#$ \\
\hline 84) & $\begin{array}{l}\text { 2-Methoxy 4-vinyl phenol } \\
\text { ethanone[59] }\end{array}$ & 2-Methoxyacetophenone & Present & \# \\
\hline 85$)$ & Tricosane[59] & Docasane & Present & \# \\
\hline 86) & $\begin{array}{l}\text { 1-[(T-butyl)-dimethyl silyl } \\
\text { thin]butane[59] }\end{array}$ & $\begin{array}{l}\text { 3-oxo-23,24-bisnorchol-4-en-22 oic } \\
\text { acid }\end{array}$ & Present & \# \\
\hline 87) & Calotropone[60] & +9 & Present & $\#$ \\
\hline 88) & Gofruside[60] & $\begin{array}{l}\text { (3S,5S,10R,13R,14S,17R)-14 hydroxy- } \\
\text { 13methyl-17-(5-oxo-2H-furan-3yl)- } \\
3[(2 \mathrm{R}, 5 \mathrm{~S})-3,4,5 \mathrm{Z} \text {-trihydroxy-6- } \\
\text { methyloxxan-2yl]oxy- } \\
\text { 1,2,3,4,5,6,7,8,9,11,12,15,16,17 } \\
\text { tetradecahydocyclopenta } \\
\text { [a]phen-10-carbaldehyde }\end{array}$ & Present & \# \\
\hline 89) & 2,3,4-trimethyl hexane[61] & Hexane, 2,3,4,trimethyl & $\#$ & Present \\
\hline 90) & Decane[61] & Decyl hydride & $\#$ & Present \\
\hline 91) & 1,3,5 Triisopropyl benzene[61] & 2,4,6-Triisopropyl benzene & $\#$ & Present \\
\hline 92) & $\begin{array}{l}\text { 4,hydroxy-4-methylpentan-2- } \\
\text { one[61] }\end{array}$ & 2-Methyl-2-pentanol-4-one & $\#$ & Present \\
\hline 93) & n-Pentadecane[61] & Pentadekan & $\#$ & Present \\
\hline 94) & $\begin{array}{l}2,6,10,15,19,23 \text {-Hexamethyl- } \\
2,6,10,14,18,22-\end{array}$ & Pentahydrosqualene & $\#$ & Present \\
\hline
\end{tabular}


International Journal of Trend in Scientific Research and Development (IJTSRD) ISSN: 2456-6470

\begin{tabular}{|c|c|c|c|c|}
\hline & tetracosahexane[61] & & & \\
\hline 95) & $\begin{array}{l}\text { 3,7,11-Trimethyl-2,6,10,12- } \\
\text { pentadecatrien-1-ol [61] }\end{array}$ & 2,3,4-trimethylhexane & $\#$ & Present \\
\hline 96) & 2,6,dimethyl tetra-1,5-decane [61] & $\begin{array}{l}\text { 4,7,Epoxyisobenzofuran-1,3 dione, } \\
\text {,hexahydro-3a,7a-dimethyl }\end{array}$ & $\#$ & Present \\
\hline 97) & (6Z),(9Z) Pentadecadien 1-ol [62] & 6,9,Pentadecadien-1-ol & \# & Present \\
\hline 98) & Farnesol isomer [62] & Polyprenol & $\#$ & Present \\
\hline 99) & Tetratetracotane [62] & n-Tetratetracotane & \# & Present \\
\hline 100) & $\begin{array}{l}\text { 2-Hexadecen-1-ol,3,7,11,15- } \\
\left.\left.\text { tetramethyl-,[R-[R* }{ }^{*}{ }^{*}-(\mathrm{E})\right]\right]-[62]\end{array}$ & Phytene-2 & $\#$ & Present \\
\hline 101) & $\begin{array}{l}\text { 9,12,15-Octadecatrienoic acid, } \\
\text { methyl ester,(Z,Z,Z)-[62] }\end{array}$ & Octadeca-9,12,15-trienoic acid & \# & Present \\
\hline 102) & $\begin{array}{l}\text { Naphthalene } \\
\text { decahydro,2,6,dimethyl }\end{array}$ & Decahydro-2,6-dimethylnaphthalene & $\#$ & Present \\
\hline 103) & 9-Octadecnoic $\operatorname{acid}(Z)[62]$ & Octadec-9-enoic acid & $\#$ & Present \\
\hline 104) & $\begin{array}{l}\text { 2-H Benzofuranone 5,6,7,7A tetra } \\
\text { hydro 4,4,7A,trimethyl [62] }\end{array}$ & $\begin{array}{l}(2,6,6 \text {-Trimethyl-2- } \\
\text { hydrocyclohexylidene)acetic acid } \\
\text { lactone }\end{array}$ & $\#$ & Present \\
\hline
\end{tabular}

[\# signifies that these do not provide any relevant information]

Isolation of Compounds from Calotropis species
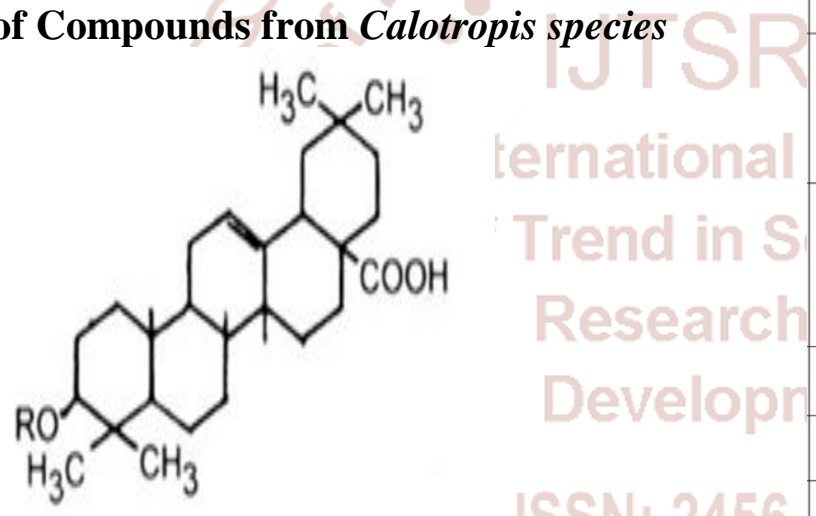

Fig.16.Two pentacyclic triterpenes Oleanic acid/ Olenic acid[56]

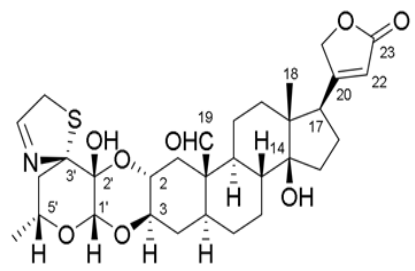

Fig.17.Chemical structures of (1)Uscharin and (2)EpiUscharin

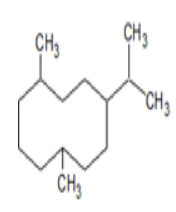

Germacrane-A

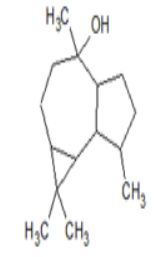

(.). - globulol

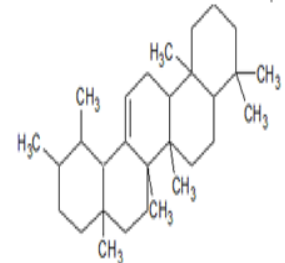

U1s.12:-ne

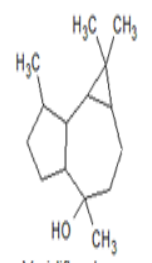

Venidiflorol
Fig.18.Compounds isolated from the stem bark plants of Calotropis gigantea [61]

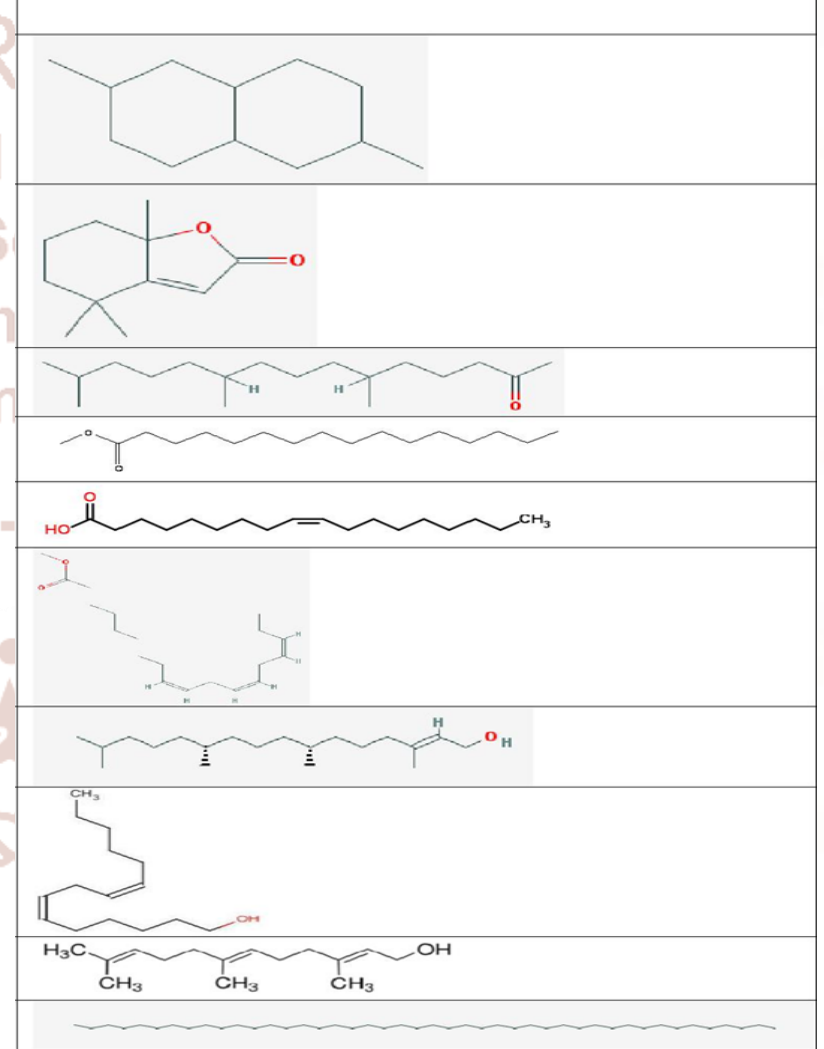

Fig.19: Napthalene decahydro2,6 dimethyl; Compound-(2):2-H Benzofuranone 5,6,7, 7A tetra hydro 4,4,7A trimethyl;Compound-(3): 6, 10,14trimethyl, Pentadecanone -2:Compound-(4):

Hexadaconic acid, methyl esters; Compound(5):9-

Octadecenoic Acid (Z)-:Compound(6):-9,12,15-

Octadecatrienoic acid, methyl ester, (Z,Z,Z)-

:Compound-7:2-Hexadecen-1-ol, 3,7,11,15tetramethyl-, [R-[R*, R*-(E)]]-Compound-8:(6Z), (9 Z) Pentadecadien 1-ol.[62] 
International Journal of Trend in Scientific Research and Development (IJTSRD) ISSN: 2456-6470

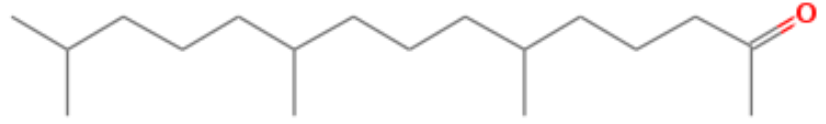

Fig.20. 6, 10, 14-trimethyl-2-Pentadecanone [63]

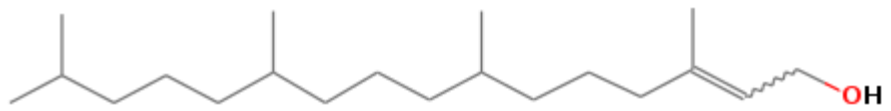

Fig.21. 3, 7, 11, 15-tetramethyl-2-hexadecen-1-ol [64]

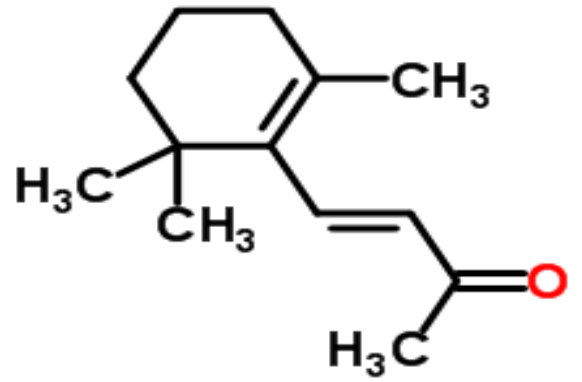

Fig.22.3-Buten-2-one-4, 2, 6, 6-trimethyl-1cyclohexne-1yl[65]

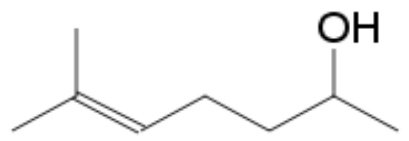

Fig.23.6-Methyl-5-hepten-2-ol [66]

Economic importance of Calotropis species

1. Calotropis spp., acts as a soil binder and prevents soil erosion. It is also used as green manure and used for mulching.[66]

2. The extracts of Calotropisspp, leaves and latex are used for Nematicidal activity.[66]

3. The fine fibre obtained from the bark of Calotropis giganteais used in making textiles, fishing net and bowstrings. It can be used to make pillows and mixed with other fibre to make clothes.[68],[71]

4. A strong fibre is obtained from the stem of Calotropis procera used for making ropes, gunny bags, fishing net, cot-ropes, bow strings and used in the manufacture of pulp and duplicating stencils (Mimeograph). [69],[72]

5. Strong inner barks from Calotropis procera are used to produce binding material and are processed into fabrics.[69],[70]

6. In Brazil, Calotropis procera is used as an animal feed as it produces green biomass and dry matter. [74]

7. The parts of Calotropis such as root, stem, leaf and flowers have vermicidal, bactericidal, emetocathratic (vomiting\& purging) and dig italic properties.[6]
8. An infusion of bark powder of Calotropis procera is used for the treatment of leprosy and elephantiasis. [6]

9. The tonic prepared from Calotropis procera is used for asthma and catarrh[6]

10. The latex is used for treating ring worm, guinea worm blisters, scorpion stings, venereal sores and ophthalmic disorders.[6]

11. The milky sap of Calotropis procera act as a rubefacient, purgative and caustic compound[6]

12. Calotropis roots are used as bio- sorbent in waste water for copper remediation.[66]

13. Calotropis which yields 90tons of biomass twice a year and is a potential source of renewable energy.[66]

14. The bark and latex of Calotropis procera are used in brewing and to curdle milk.[19]

15. The twigs of Calotropis proceraare applied for the preparation of diuretics, stomach tonic, antidiarrhoeic, asthma, abortion, anthelmintic, cough, dysentery, head ache, lice treatment, jaundice, sore gums mouth toothache, sterility, swellings and ulcer.[19]

16. A macerated bark of Calotropis procera extract can be used for dehairing and tanning in the leather industry.[19]

17. Calotropis procera acts as an ideal plant for monitoring sulphur dioxide emissions in the air.[19]

18. Stems of Calotropis procera produce a type of charcoal. In India, they are used in making gun powder.[19]

19. Stems of Calotropis procera are used for roofing and building huts.[19]

\section{Reference:-}

1. Pramila kori, Prerana alawa,"Antimicrobial activity and phytochemical analysis of Calotropis gigantea root, latex extracts"IOSR Journal of Pharmacy,4(6).,07-11,2014.

2. Poonam Sethi "Morphological, Microscopical, Physico-chemical and Antimicrobial investigations on leaves of Calotropis gigantea Linn" International Research Ayurveda Pharm, 5(2)., 193-197,2014.

3. Calotropis gigantea. $R$. Br., "Bulletin of Miscellaneous information, Royal Gardens Kew"1htt900; 8(12).,157-168.

4. http://www.the plantlistorg/Calotropis/tpl/record/kew-2639659. 
5. Samantha Krishanu and Mishra Divyansh, "Preliminary Physico-Phytochemical and PhytoCognostical Evaluation of the leaves of Calotropis gigantea (L).R.Br', International Journal of Pharmaceutical and Chemical sciences, 2(4), .2277-5005, 2013.

6. Anil Kumar Sharma, Rajeev Kharb and Raja deep Kaur "Pharmacognostical aspects of Calotropis procera(Ait) R.Br" ,International Journal of Pharma and Bio sciences.,2(3),.480-488,2011.

7. http://indilvibe.indel.corp.co.in/Calotropis-aciaeruku-a-medicinal plant.

8. http://www.efloras.org/florataxon.aspx $\{\mathrm{e}$ Flora Nepal checklist 24 Feb2009[1]\}

9. Sony J. Chundattu, Vijay Kumar Agarwal, N.Ganesh, "Phytochemical investigation ofCalotropis procera",,Arabian Journal of Chemistry., 9(1).,230-234,2014.

10. Madhurima Dutta, Sarmistha Rej, Shahid Jamal,Sumanta Das and Sabyasachi Chatterjee,"Study of Phytochemical constituents and Antibacterial activity of Calotropis gigantea" International Science Journal.,1(4),15-28,2014.

11. http://www.feedipedia.Calotropisprocera.org/nod $\mathrm{e} / 588$

12. http://www.flowersofIndia/net/catalogue/slides/cr own $\% 20$ flower/html

13. http://www.stuartX change.org/kapal-kapal/html.

14. http://Calotropisacia.Observation on taxonomical characters.

15. http://India biodiversity.org/sps/show 32452.

16. DietmarBrandes(2005)"Calotropis procera on Fueteventura"3(4)., 1-7

17. RudolfMansfield, R. Buttner (2001) “Calotropis procera in Laos"., Mansfied'sEncyclopedia of Agriculture and Horticultural crop,1(3)., 12-3412.

18. http://www.proto.org.protobase -plant resources of tropical Africa.

19. www.world.agro forestry

20. http://www.efloraofgandhinagar.in/shrub/Calotrop isprocera.

21. http://www.biologydiscussion.com/plants/flowerin g plants/family Asclepiadaceae.

22. www.missuouri botanical garden.org/Calotropis procera/plant finder.
23. www.hear.org/pier/sps/Calotropisgigantea/html

24. R. Ramasubramania Raja, N. Kishore, M. Sreenivasulu, S. KRasoolBee, S. Nandini, L. Ooha, N. Chaitanya, "Calotropis giganteabotanical, pharmacological view"., Journal of Medicinal Plants Studies,.4(3),87-89.

25. www.species.Calotropis procera. Medicinal herbs.com.

26. www.asgreen.Calotropis procera.com.

27. www.smart seedstore.com.

28. www.dwasgarden.com

29. https://www.arkive.org>Calotropisprocera

30. http://www.hort.pudre.edu/newcrop/factsheets/Cal otropis.hml

31. Www.shutterstock.com/search/milkweed+plant.

32. monarchbutterflygarden.net/milkweed-plantseeed.

33. Preknature-Calotropis gigantea

seed pod.www.treknature.com

34. www.floraofgandhinagar.in/shrub/Calotropis procera.

35. Flora of China-Calotropis. R. Brown, Mem, Wem, Nat,Hist.Soc. 1:39:18:10

36. Parhira. S, Zhu. G. Y, Jiang. R. W, Liu. L, Bai. L. $\mathrm{P}$, "2'Epi-uscharin from the latex of Calotropis gigantea with HIF-1 inhibitory activity", Scientific Report, 4(1), .47-48, 2014.

37. Mossa. J. S, Am. J. Chin Med "Pharmacological studies on aerial parts of Calotropis procera"The American Journal of Chinese Medicine, 19(34),.223-231,1991.

38. Hasder.M,"Worldparts:Synonymicchecklistof vascular plants" Digital resource,.2(1).,2458,2018 .

39. A.Shrivastava,Suchit Singh,Sanchita Singh "Phytochemical investigation of different plant parts of Calotropis procera" International journal of Scientific and Research publications 3(8),.24,2013.

40. Suchita Singh,Sanchita Singh, R.M.Mishra, Mahesh Pal Shrivastava, "Preliminary Phytochemical Screening of Calotropis gigantea Leaf " International Journal of Scientific and Research Publications"4(2).,1-3,2014. 
International Journal of Trend in Scientific Research and Development (IJTSRD) ISSN: 2456-6470

41. Kalaivani Radhakrishnan, Paneerselvam Thangamani and Vedha Balakrishnan "Antibacterial and Phytochemical analysis of stem and root extracts of Calotropis gigantea against pathogens" Malaya Journal of Biosciences., $1(1), 49-55,2013$.

42. Pradeep Deshmark, Tanji Nandgude, Mahendra Singh Rathode, Anil Midha,Nithin Jaiswal,"Hepatoprotective activity of Calotropis gigantea root bark experimental liver damage by D-Galactosamine in rats" International Journal of Pharmaceutical Sciences and Nanotechnology.,1(3),281-286,2008.

43. David .M,Bharath.K.R, Bhavani.M "Study of Calotropis giganteaR.Br.Extracts on Growth and survival dynamics of Selected pathogenic microorganisms" International Journal of Biological Engineering 1((1),,1-5,2011.

44. Gaurav Kumar,Loganthan Karthik,Kokati Venkata BhaskarRao"Antibacterial activity of Aqueous extract of Calotropis gigantea leaves An In vitro study" International Journal of Pharmaceutical Sciences Review 12 and Reseach"4(2).,141-144,2010.

45. Manju singhi,Vinod Joshi and P.K.Dam,"Studies on Calotropis procera as larvicide and repellent plant against vectors of dengue and $\mathrm{DHF}_{\text {in }}$ Rajasthan,India"Journal of vector borne diseases.,47(3).,1-5,2004.

46. Nadia Hussein Mohamed, Mady Ahmed Ismail,Wael Moutfa Abdel-Mgeed,AhmedAbdel Fattah Mohamed Shoreit "Anti-microbial activity of latex siver nanoparticles using Calotropis procera" Asian Pacific Journal of Tropical Biomedicine.,4(11),876-883,2014.

47. Vidya.C,ShilpaHiremath,M.N.Chandraprabha,M. A.LourduAntonyraja,Indu Venu Gopal,Aayushi Jain and Kokil Bansil "Green synthesis of Zno Nanoparticles by Calotropis gigantea" International Journal of Current Engineering and Technology"., 1(1),.118-120,2013.

48. Hanaa I.Fahim,Osama .M.Ahmed,Magdy. W.Boules,Heba.Y.Ahmed,"Nephrotoxic effects of Abamectin and Calotropis procera latex and leaf extract in male albino rats" American Journal of Medicine and Medical science., 6(3).,73-86,2016.

49. R.S.Gupta,Nutan Sharma and V.P.DixiT, "Calotropin-Anovel compound for fertility control" Ancient Science Life,.9(4).,224230,1989 .

50. Ga.Bakavathiappan,S.Baskaran,M.Pavaraj and S.Jeyaparvati, "Effect of Calotropisprocera leaf extract on Spodoptera lithura(Fab)" JBiopest,5(1),.135-138,2012.

51. H.R.Chitme"Studies on Anti-diarrhoeal activity of Calotropis gigantea .R. Br.in experimental animals" J Phar Pharmaceuticals Science., 7(1)., 70-75,2004.

52. Rama Aggarwal, Upma Baghai, "Impact of Anthelmintic efficacy of Calotropis procera on Tegumental enzymes of the trematode, Gastrothylax indicus" IOSR Journal of Pharmacy,.4(8).,26-36,2014.

53. Vinay Kumar Mishra, Abhishek Nagori and Saima Sheikh"Anti diarrheal activity of Ethanolic extract ofCalotropis procera R.Br." Journal of Pharmaceuticals.,2(1).,1-6,2013.

54. Vipin Nagda, Archana Gajbhiye, "Isolation and characterisation of endophytic fungi from Calotropis procera for their anti-oxidant activity" Asian Journal of Pharmaceutical and Clinical Research., 10(3).,254-258,2013.

55. W.Okiei,M.Ogunlesi,E.Ofor and E.A.S.Osibote "Analysis of Essentialoil constituents in hydrodistillates of Calotropis proceraR.Br.Roots" ., Research Journal of Phytochemistry,3(3).,4453,2009 .

56. Minakshi Singh and Kalim Javed "Comparative study of Chemical composition of Calotropis gigantea flower, leaf, fruit essential oil" .,Eur.Chem.Bull.,4(10).,477-480,2015.

57. Aditi Gupta, Rachana Singh, Chhavi Purwar, Deepa Chauhan and J.Singh,"Two pentacyclic triterpenes from the stem of Calotropis procera"., Indian Journal of Chemistry.,42(2),.20302033,2003.

58. Kamel.H.Shaker, Nagy Morsy, Heidi Zieniecker, Johannes.F.Imhoff, Bernd Schneider "Secondary metabolites from Calotropis procera (Aiton)" .,Phytochemistry Society of Europe .,3(1).,212216,2010.

59. Shalini Sharma, Amita Kumari,Mamta Sharma"Comparitive GC-MS Analysis of bioactive compounds in Methanoic extract of Calotropis gigantea(L)W.T.Ation leaf and latex" 
International Journal of Trend in Scientific Research and Development (IJTSRD) ISSN: 2456-6470

International Journal of Pharmacognosy and Phytochemical Research.,8(11).,1823-1827,2016.

60. Zhu-Nian Wang, Mao-Yuan Wang,Wen-Li Mei and $\mathrm{Hao}-\mathrm{Fu}$ Dai, "Anew cytotoxic pregnanone from Calotropis gigantea" Molecule Journal.,13(1).,3033-3039,2008.

61. Hiren.V.Doshi,Farzin.M.Parabia,Falguni.K.Sheth, Indravadan.L.Kothari,Minoo.H.Parabia,Arabinda Ray " Phytochemical analysis revealing the presence of two new compounds from the latex of Calotropis procera(Ait).R.Br.,2(2),.28-30,2012.

62. Manal. Y.Saameeh, Amal. A.Mohamed "Characterisation of polyphenols by HPLC, their anti-oxidant and GC-MS analysis of wild Calotropis procera leaves and fruit extracts" International Research.,11(01).,319-327,2018.

63. webbook.nist.gov/cgi/book.cgi

64. webbook.nist.gov/cgi/cbook.cgi

65. http://webbook.nist gov>cgi.c book

66. Calotropisgigantea.http:// feedpedia.org/node/588

67. R.Reena Loice, P.Parthiban,A. Leo Standly, "The effect of Calotropis gigantea leaf extract on growth control of Struvite crystals" International
Research Journal of Engineering and Technology(IRJET).,5(2).,805-817,2018.

68. www.tropical.theferns.info>viewtropicalcalotropis gigantea.

69. www.tropicalthe ferns.info>view tropical Calotropis procera.

70. NazillaTarabi,HosseinMousazadeh,AliJafari,Jalli Taghizadeh-Tameh, "Design, construction and evaluation of fibre extracting machine from Calotropis procera stem" Engineering in Agriculture, Environment andFood Science direct Article.,8(2).,88-94,2015.

71. AllirezaAshori,ZakerBaherini "Evaluation of Calotropis gigantea as a promising raw material for fibre-reinforced composite" Journal of Composite materials.,43(11).,1297-1304,2009.

72. Somnath Maji," Extraction of high quality cellulose from the stem of Calotropis procera" South Asian Journal.,3(3).,113-118,2013.

73. Isaias Vitorino Batista De Almeida, Diogo Gonçalves Nesder, Fabiane Rabelo Da Costa Batista,Wellison Filgueiras Dutra, "Characterization and early selection of silk blossom (Calotropis procera) genotype with forage potential" Revista Caatinga journal $., 30(3) ., 1983-2125,2017$. 